\title{
Forms and Extent of Ferrugination in Soils of Georgia
}

\author{
Lia Matchavariani $^{1}$, Dali Nikolaishvili ${ }^{2}$ \\ ${ }^{1}$ Department of Soil Geography, Faculty of Exact \& Natural Sciences, Iv Javakhishvili Tbilisi State University, Tbilisi, Georgia \\ ${ }^{2}$ Department of Geomorphology \& Cartography, Faculty of Exact \& Natural Sciences, Iv Javakhishvili Tbilisi State University, Tbilisi, \\ Georgia
}

Email address:

lia.matchavariani@tsu.ge (L. Matchavariani),dali.nikolaishvili@tsu.ge (D. Nikolaishvili)

\section{To cite this article:}

Lia Matchavariani, Dali Nikolaishvili. Forms and Extent of Ferrugination in Soils of Georgia. American Journal of Environmental Protection. Special Issue: Applied Ecology: Problems, Innovations. Vol. 4, No. 3-1, 2015, pp. 157-161. doi: 10.11648/j.ajep.s.2015040301.34

\begin{abstract}
Ferruginization as one of the most characteristic processes in soils of Georgia, has been investigated both qualitatively and quantitatively mainly micropedologically, by polarizing microscopy on thin sections. A study was undertaken to determine some of pedological factors affecting the genesis of Fe-formations in soils series of West and East Georgia. This process is diagnosed by the presence of different forms of ferrous formations, concentration level or iron crystallization, ferruginized micro-zones of plasma impregnation with ferric hydroxides, etc. A map showing the distribution of the ferrugination process in the soils of Georgia was created.
\end{abstract}

Keywords: Ferum hydroxides, Concretions, Distribution, Georgia

\section{Introduction}

The movement of water in soil profiles, carry with it the soluble constituents, mostly iron. Subsequently, these solutes are deposited and segregated in neoplasms. Concretions of some kind are found in most soils, where they have been formed by secondary processes [1].

Origin and development of ferruginous concretions are widely distributed in many regions of the Earth, including humid subtropical of Georgia. Their distribution, morphology, physical speciation, chemical composition and other parameters were investigated by many authors in the $50-90$-years of the last century as well as as in recent years [2, $3,4,5]$. In details morpho-genetically typification of soil $\mathrm{Fe}$ and Fe-Mn concretions, with the use of complementary research methods at the macro-, meso-, micro- and submicro-levels have been studied in Georgia [6].

The humid subtropical soils of Georgia have the properties associated with the movement and/or transformation of iron in the profile (in respect of both, concretion-formation and impregnation of the basic soil mass) what is caused by the manifestation of a number of the elementary soil processes attributed to the group of hydrogen-accumulative (lateralization, plinthification), and metamorphic (ferrugination, ferrallitization, rubification) processes. The listed processes take place in the soils of Georgia at a more or less degree [7].
Lateralization - a hydrogen-accumulative process of allochthonic intra-soil ferrugination by forming strong concretionary or iron-clad interlayers of different structures. Lateralization is a process of both, old and modern ferrugination causing the exclusion of the significant amounts of iron and aluminum from the cycle leading to the formation of interlayers of different structures, different densities and correlations of $\mathrm{Fe}, \mathrm{Al}$, Si by accumulating the iron from the ground or soil waters during the lateral movement through the accumulative landscapes. A lateral layer may also be formed by the metamorphization of plinthite. Usually, a laterite with its unbroken structure in the soil profile has a binomial composition: the upper, concretionary (which can be formed independently from plinthite-formation) and lower - tabular (the result of a plinthite formation and solidification).

Plinthification - a hydrogen-accumulative process of transformation of the ferraliticized material by means of precipitation of the iron oxides from the rising ground waters on the kaolinite matrix.

Ferrugination - a metamorphic process of the iron liberalization from the minerals during their weathering and sedimentation in situ in the pores and cracks as autochthonic cutans of grains and micro-aggregates and clumps of hydroxides accompanied by brown or red coloration of the soil-forming rock.

Ferrallitization - a metamorphic process of intra-soil weathering of primary minerals by forming and relative 
accumulation in situ of the secondary clay of the ferralitic content. The leading component of a ferraliticized material is quartz, kaolin and minerals of the group of aluminum and ferric hydroxides.

Rubification (ferritization) - a metamorphic process of an irreversible coagulation and further crystallization of colloid ferric hydroxides in the soil profile as a result of intense periodic drying of soil in the dry and hot period of the year after they are introduced and precipitated in the wet period of the year.

Morphologically, the specifics of ferric neo-formations lie in that they are easily differentiated in the mixed mass with their content and structure. The most important criterion of the micromorphological diagnostics of Fe-formations is the degree of concentration or crystallization of substances [4]. Ferrugination on its turn, is also an important diagnostic sign of gleying.

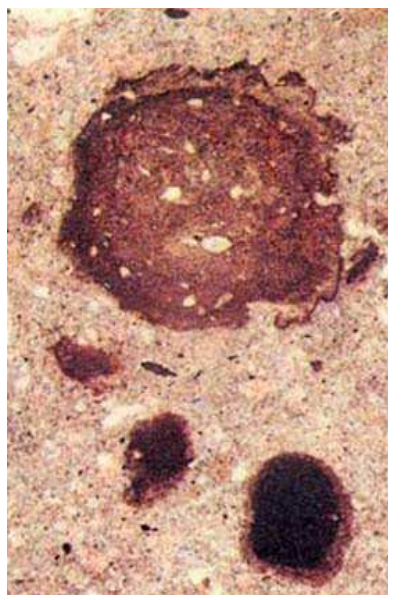

(a)

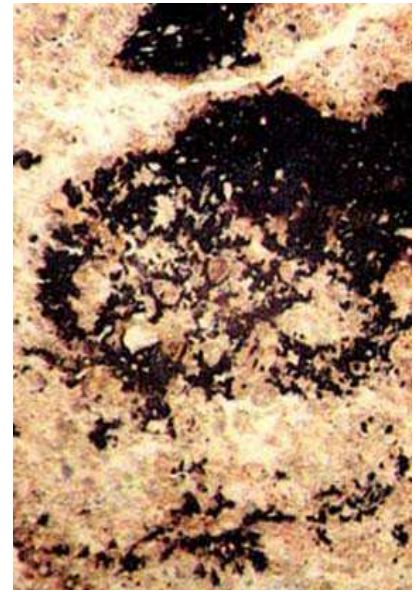

(b)
Figure 1. Forms of iron (a) and manganese (b) compounds in soils, nic.II

Neo-formations of iron compounds in fact, are found in all soils of humid territories $[6,7]$. They are easy to recognize with their rusty-brown, reddish or yellowish-brown coloration in transmitted or reflected light; they are often isotropic except the crystals of goethite, hematite, etc.

Spots and flakes, dissipated in the basic mass, rarer than threads on the grains of the skeleton are the proof of the presence of less intense local processes of iron liberalization in situ. Separate or dissipated flakes can be the remains of organic-ferric complexes after their organic components are decomposed, or the result of $\mathrm{Fe}$ concentration with microorganisms, or the result of the local re-distribution of hydroxides.

Diffusion rings and strips are thin, continuous or discrete, single or complex (through concentric), ranging from the light rusty or orange through the blackish-brown color; they are always clearly distinguished in the basic mass. They are made of fine-dispersed Fe hydroxides, and organic-ferric complexes may also present. Sometimes, the diffusion rings are associated with the root conducting pores, i.e. the root excretions seem to cause the mobilization and re-distribution of hydroxides. The strips show the certain levels of ground waters, i.e. they are components of pseudofibers. The strips are profile traces of the near-root hydroxides concentrations, or they are formed in the periodically overwetted areas in terms of heterogeneous structure and grain size in the contact zone. Biogenic forms of hydroxides with low concentrations include ferruginized vegetation remains - ferruginous pseudomorphs in organic tissues.

Ferrous tubes or so called Rohrensteins (rhyzo concretions) are considered as a result of the further concentration of a substance in the near-root zones. As compared to diffusion rings, they are larger in size and have more impregnated basic mass along the root conducting pores of $\mathrm{Fe}$ or $\mathrm{Mn}$ compounds and humus substances. They are mostly typical to humus-accumulative horizons of soils of ground bogging.

Ferrous-manganous cutans, being the immediate product of illuviation, may be purely ferrous or manganese-ferrous. Often, they alternate with clay sinters. Purely manganese films, the manganese, easily recognizable by their black color with a metallic gleam, are rarer. Their typical forms are dendrites (fillers in thin, branched-out pores) and ferrous-manganese pseudomorphs on the vegetation remains.

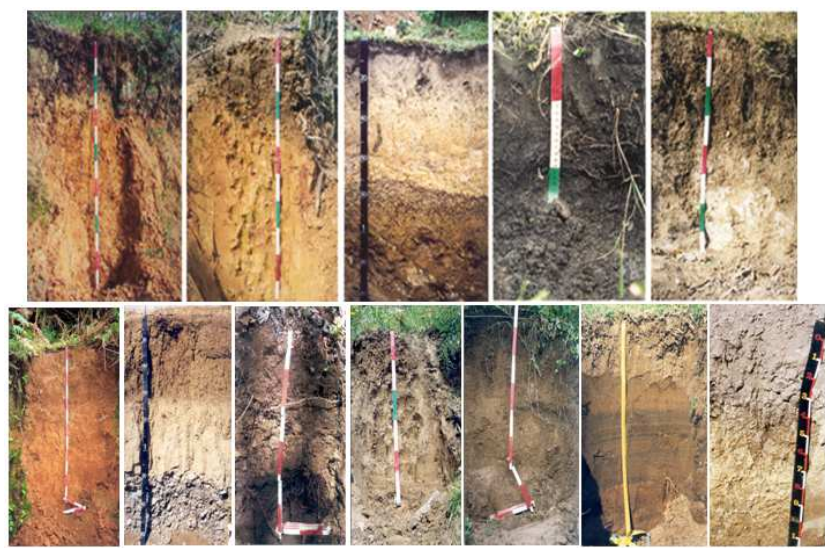

Figure 2. Spectrum of genetic profiles Georgia's soils.

Concretions, micro-ortshteins, nodules - the forms of formations with more diversified content and appearance at high concentrations of ferrous substance. In addition to iron and manganese, these neo-formations include humus compounds and components of the basic mass. Many concretions include skeleton grains perhaps because they are formed through the segregation of hydroxides under favorable terms - skeletal micro-zones. Inclusion of the clay material in the concretion, papules in particular, is a clear evidence of the heterochrony of illuviation and concretion-formation. The morphology of the concretionary forms, particularly, of those inherited from the soil-forming specimens, is quite diversified.

Morphologically, the simplest of the concretionary forms is micro-ortshteins. Large micro-ortshteins can be fixed in a morphological profile as "leather coats". Micro-ortshteins are typical to elluvial horizons of soils with a texture-differentiated profile and can be considered a reliable criterion of surface gleying. Concretions can be of different forms; they contain Fe and Mn hydroxides, humus compounds 
and inclusions of skeletal grains. Concentric concretions are most often found in the upper horizons owing to the dynamics of the conditions of humidification and oxidation-reduction processes. The concretions with even distribution and high concentrations of hydroxides are sometimes called nodules.

The structure of ferrous-clay plasma is mainly described based on Kubiena's works [8], which contribution to micropedology has been evaluated in recent publications of G. Stoops $[9,10]$. Initially, the ferrous-clay plasma is usually sub-divided into two types: plasma with the evenly distributed amorphous ferric hydroxides and plasma, in which amorphous ferric hydroxides present as clots. It is also classified by color: brownish-ocherous, yellow, red or greenish-grey plasma. The presence or absence of the crystallized forms of iron oxides is also considered.

Plasma of the first type. The brownish-ocherous plasma is a dense, fine-pored mass. Iron oxides in it are distributed diffusively. In Kubiena's opinion, such kind of plasma is mostly formed in terms of permanently humid subtropical climate. Yellow and red plasmas are typical of the soils in the subtropical zones with variable humidity. In the reflected light, the color of the yellow plasma has a brighter eggyolk yellow tint than in the transmitted light, while red plasma looks orange-red. Greenish-grey plasma is widely spread in gley soils. Usually, in case of irregular manifestation of the oxidation-reduction processes, a marble-like coloration occurs as spots of greenish, grayish, rusty-brown or ocherous color showing the different states of iron oxides.

Plasma of the second type includes: brown plasma with earthly appearance typical to the mountainous areas; loose, well-aggregated, highly porous, coagulated with ferric hydroxide, hardly transformable to a crystalline state; yellow with a red tint, typical to the soils of humid subtropics; includes many fine bright red coagulated lumps of ferric hydroxides; is characterized by a large number of Fe-concretions and spots, which are bright red in the reflected light.

\section{Study Area and Methods}

The object of the studies in fact, covers the entire soil spectrum of Georgia, which is characterized by a variety of soil types, spread on a small territory. Complicated geological structure, heterogeneity of relief, contrasting climatic conditions, the specificity of vegetation and biodiversity, comprehensively define a variety of soil cover of the country (Mountain Meadow; Brown Forest; Yellow-Brown; Mountain Chernozems; Raw Humus Calcareous; Chernozems; Cinnamonic; Meadow Cinnamonic; Grey Cinnamonic; Meadow Grey Cinnamonic; Salt Soils; Red Soils; Yellow Soils; Subtropical Podzolic; GleyPodzolic; Alluvial; Bog Soils).

The macro- and micromorphological descriptions were done in compliance with well-known guides and information manuals in micropedology $[11,12,13]$. In order to determine the common geographical regularities of formation and distribution of various types ferruginous segregations in soils of Georgia, the detailed micropedologic studies by using the systems of mutually complementary coupled macro-, mezzo-, micro- and sub-micromorphological methods, which clearly evidence the mechanism of formation of the genetic profiles of soils were used [6].

The taxonomic units of the national soil classification of Georgia (fig. 2), according to WRB [14] are systemized in following relation: Cambisols (Mountain Meadow, Meadow Grey Cinnamonic, Cinnamonic, Cinnamonic Calcareous, Meadow Cinnamonic); Umbrisols (Mountain Forest Meadow of West Georgia); Leptosols (Mountain Forest Meadow of East Georgia); Luvisols (Yellow Soils, Yellow Brown Forest); Faiozems (Mountain Meadow Chernozem like); Nitisols (Red Soils); Acrisols (Subtropical Podzols); Chernoziom (Vertisols); Kashtanozems (Grey Cinnamonic); Fluvisols (Alluvial Soils), etc.

\section{Results and Discussions}

Table 1. The Ratio of Ferrugination among Profile-formation Process in maim Soils of Georgia.

\begin{tabular}{|c|c|c|c|c|c|}
\hline \multirow{2}{*}{ Soil Types } & \multicolumn{5}{|c|}{ Soil-forming Processes } \\
\hline & $\mathbf{F e}$ & $\mathbf{L s}$ & GI & $\mathbf{C b}$ & $\mathbf{H ~ m}$ \\
\hline Brown Forest & ++ & ++ & + & - & ++ \\
\hline Yellow-Brown & ++ & ++ & ++ & - & ++ \\
\hline Mountain Chernozems & + & ++ & + & - & +++ \\
\hline Raw Humus Calcareous & + & ++ & - & +++ & + \\
\hline Chernozems & + & + & + & +++ & +++ \\
\hline Cinnamonic & - & + & - & +++ & +++ \\
\hline Meadow Cinnamonic & + & + & + & +++ & +++ \\
\hline Grey Cinnamonic & - & + & - & +++ & ++ \\
\hline Meadow Grey Cinnamonic & + & + & + & +++ & + \\
\hline Salt Soils & + & ++ & ++ & +++ & + \\
\hline Red Soils & +++ & +++ & ++ & - & ++ \\
\hline Yellow Soils & +++ & ++ & ++ & - & ++ \\
\hline Subtropical Podzolic & +++ & +++ & $\begin{array}{l}++ \\
+\end{array}$ & - & + \\
\hline Gley Podzolic & +++ & +++ & $\begin{array}{l}++ \\
+\end{array}$ & - & + \\
\hline Bog Soils & +++ & +++ & + & - & + \\
\hline Alluvial & ++ & ++ & + & + & + \\
\hline
\end{tabular}

Fe - Ferrugination; Ls - Lessivage; Gl - Geying; Hm - Humification; $\mathrm{Cb}$ Calcareousness.

In the soils of Georgia, the processes associated with the ferum hidroxides sedimentation, movement and transformation, were identified in many soils, particularly in the soils of the humid subtropics (Red Soils; Yellow Soils; Subtropical Podzolic; GleyPodzolic; Alluvial; Bog Soils); quite many signs of ferrugination are also seen in Brown Forest Soils as small micro-zones of segregation and impregnation of plasma. Partially ferrous extractions are seen in arid regions, as well. In the Salt Soils, sometimes there are iron extractions observed as small micro-concretions being an immediate result of the past phases of soil-formation. Depending on the kind of manifestation, it is easy to identify two forms of the ferrugination in the soils of Georgia: concretionary and plasma ferrugination, though in many soils of a humid subtropical type, it is manifested virtually in both forms - as concretionary formations ( $\mathrm{Fe}$ and $\mathrm{Fe}-\mathrm{Mn}$ ) and zones 
of ferrugination impregnated in the basic mass (fig. 1). This is why the gradation of ferrugination for the soils of Georgia was basically done by considering the intensity of the process, manifestation: strongly ferruginated, moderately ferruginated and weakly ferruginated.

The Ratio of manifestation the ferrugination among other soil process, which are forming the main soil profiles of Georgia, is given in table 1 .

Iron compounds as concretionary partings and/or deposited cemented layers in the profile, or zones of ferrugination are most common in the subtropical Podzols of Georgia (the most discussible and disputable soils in a genetic respect). The most informative source for a thorough study of the given question is the complex of micromorphological methods. Consequently, special detailed studies of Fe-formations were accomplished by using the complex of coupled micromorphological methods (including micro- and submicroscopy), and the last chapter of the present work is dedicated to this question.
Thus, the process of ferrugination in the soils of Georgia in a micromorphological respect, is diagnosed by the presence of different forms of ferrous formations, degree of concentration or crystallization of iron, character of ferruginized micro-zones or zones of plasma impregnation with ferric hydroxides, etc.

The map, showing the distribution of the ferrugination process in main soils of Georgia, has been drawn up (fig. 3). We have identified three stages of intensity the manifestations of this process: strong ferrugination, which is typical for Red soils, Yellow soils, Subtropical Podzolic and Gley Podzolic and Bog soils; moderate ferrugination, characterizes Brown Forest and Yellow-Brown soils and partly Alluvial Soils); manifestation of weak ferrugination observed sometimes in Mountain and Plain Chernozems, Meadow Cinnamonics and Raw Humus Calcareous soils, Meadow Grey Cinnamonic and Salt Soils. In Cinnamonic and Grey Cinnamonic soils epy ferrugination process practically no fixed.

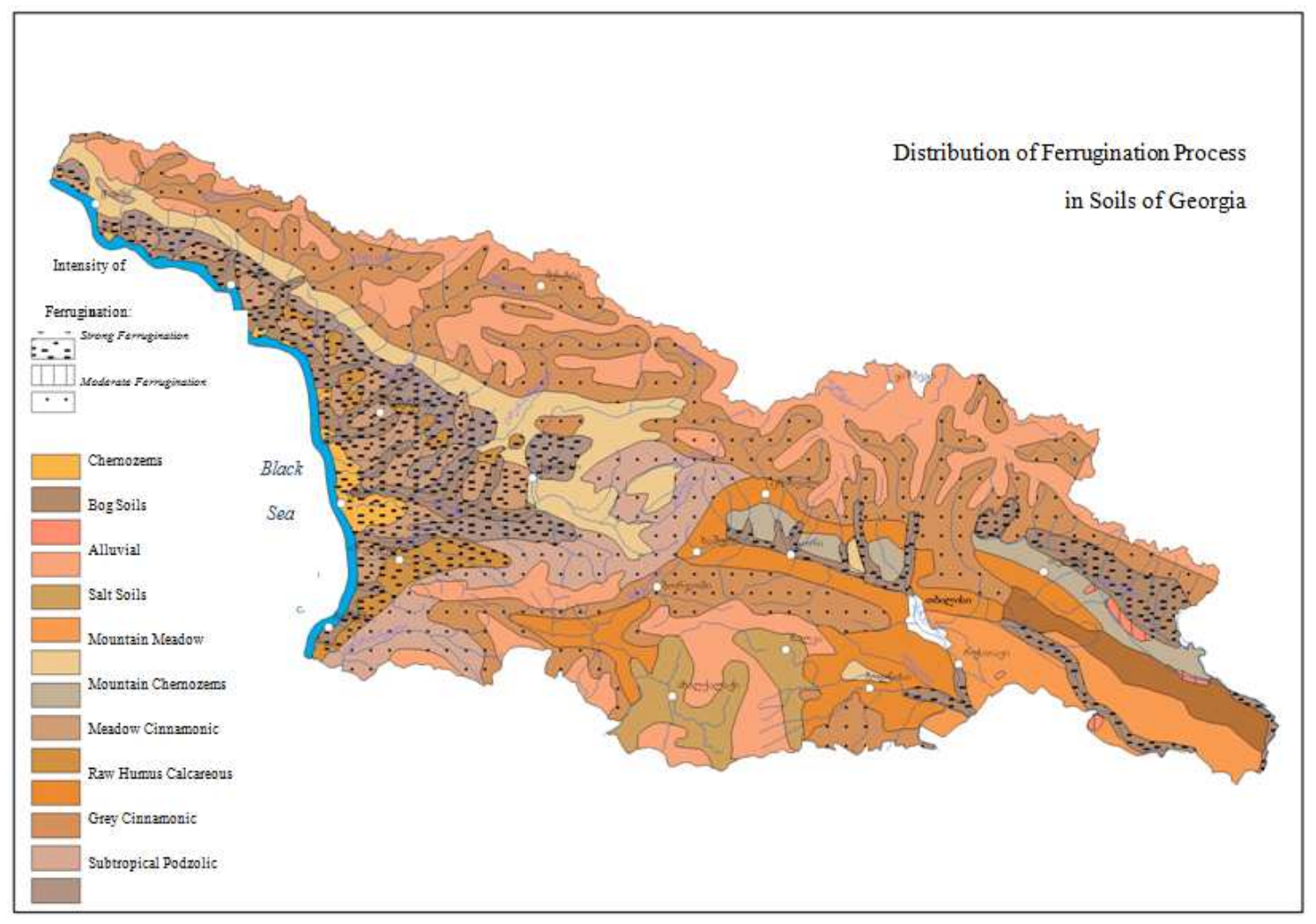

Figure 3. Distribution of Ferrugination Process in Soils of Georgia.

\section{Conclusions}

Ferruginization is one of the most characteristic processes in soils of Georgia, especially in the humid subtropical regions. The process of ferrugination in the soil profiles in a micromorphological respect, is diagnosed by the presence of different forms of ferrous formations, concentration level or iron crystallization, character of ferruginized micro-zones or zones of plasma impregnation with ferric hydroxides, etc. A map showing the distribution of the ferrugination process in the soils of Georgia was created by using software GIS.

\section{References}

[1] Buol S.W., Southard R.J., Graham R.C. and McDaniel P.A. Soil Genesis and Classification. ISBN 0-8138-2873-2. 5th Edition. Ames, Iowa: Iowa State Press, A Blackwell Pub. Co., 2003, $494 \mathrm{p}$.

[2] Latrille C., Elsassb F., Oort F.Van, Denaix L. Physical speciation of trace metals in $\mathrm{Fe}-\mathrm{Mn}$ concretions from a rendzic lithosol developed on Sinemurian limestones (France). Geoderma, Elsevier, vol. 100, issues 1-2, 2001, pp. 127-146 
[3] Gasparatos D.. Fe-Mn Concretions and Nodules to Sequester Heavy Metals in Soils. Environmental Chemistry for a Sustainable World, Springer, 2012, pp 443-474

[4] Gasparatos D. , Haidouti C. , Tarenidis D. Characterization of iron oxides in Fe-rich concretions from an imperfectly-drained Greek soil: a study by selective-dissolution techniques and X-ray diffraction. Archives of Agronomy and Soil Science, vol. 50 , issue $4-5,2004$, pp. $485-493$

[5] Jokova M., Kerchev G., Dilkova R. Relation between Waterlogging Degree and Behaviour of Mn and Fe Extractable Compounds along Depth of Textural Differrentiated soils. Почвознан., агрохим. и екол. (болг.), 2000, 35, №5, p.24-30

[6] Matchavariani L.G. Morphogenetic Typification of Concretions in Subtropical Podzolic Soils of Georgia. Eurasian Soil Science, Springer, ISSN: 1064-2293, 2005, vol. 38, \#11, 1161-1172

[7] Matchavariani L.G., Geographic Paradigms of the Microfabrics of Major Soils of Georgia, Universal, Tbilisi, 2008, 300 p.

[8] Kubiena W. Micromorphological Features of Soil Geography. New Brunswick, New Jersey, 1970
[9] Stoops G. The "Fabric" of soil micromorphological research in the 20th century - A bibliometric analysis. Geoderma, 2014 Elsevier. Volume 213, January 2014, 193-202

[10] Stoops G. Evaluation of Kubiëna's contribution to micropedology. At the occasion of the seventieth anniversary of his book "Micropedology". Eurasian Soil Science, vol.42, \#6, 2009, Springer, 693-698

[11] Jahn R., Blume H.-P., Asio V.B. Students Guide for Soil Description, Soil Classfiication, and Site Evaluation. Halle, 2003.

[12] Bullock P., Fedoroff N., Jongerius A., Stoops G., Tursina T. Handbook for Soil Thin Section Description. Waine Research Publishing, Wolverhampton, Albrigton, UK, 1985

[13] FitzPatrick E.A. Micromorphology of Soils. Chapman and Hall, London, 1984

[14] World reference base for soil resources. FAO UN, World Soil Resources Reports - 103, Rome, 2006, 128 p. 